Journal of Applied Pharmaceutical Science Vol. 7 (04), pp. 089-095, April, 2017

Available online at http://www.japsonline.com

DOI: $10.7324 /$ JAPS.2017.70412

ISSN 2231-3354 (cc) EY-NC-SA

\title{
GC-MS analysis and in-silico antipsychotic activity of Morinda citrifolia (Indian Noni)
}

\author{
Srikanth Jeyabalan $^{1 *}$, Kavimani Subramanian ${ }^{2}$, Uma Maheswara Reddy Cheekala ${ }^{1}$, Chitra Krishnan ${ }^{3}$ \\ ${ }^{1}$ Department of Pharmacology, Faculty of Pharmacy, Sri Ramachandra University, Porur, Chennai - 600 116, Tamil Nadu, India. \\ ${ }^{2}$ Department of Pharmacology, Mother Theresa Post Graduate and Research Institute of Health Sciences, Puducherry - 605006, India. \\ ${ }^{3}$ Department of Pharmaceutical chemistry, Faculty of Pharmacy, Sri Ramachandra University, Porur, Chennai - 600 116, Tamil Nadu, India.
}

\begin{tabular}{|c|c|}
\hline ARTICLE INFO & ABSTRACT \\
\hline Article history: & \multirow{6}{*}{$\begin{array}{l}\text { Morinda citrifolia (Noni) has been used for centuries to cure or prevent variety of illnesses by traditional } \\
\text { medical practitioners in Hawaii and Polynesia. The aim and objective of the present study is to perform GC-MS } \\
\text { analysis of Morinda citrifolia fruit extract and in-silico docking analysis of the phytoconstituents identified in } \\
\text { Morinda citrifolia fruit extract against targets for antipsychotic drugs like dopamine receptors }\left(\mathrm{D}_{2} \text { and } \mathrm{D}_{3}\right) \text {. GC- } \\
\text { MS analysis was performed and the phytoconstituents of Morinda citrifolia were retrieved from pubchem } \\
\text { compound databases. The standard typical antipsychotic and atypical antipsychotic drugs were obtained from } \\
\text { drug bank in .mol format. The 3D protein structures of the targets dopamine receptor } \mathrm{D}_{2} \text { (PDB ID: } 5 \mathrm{AER} \text { ), } \\
\text { dopamine receptor } \mathrm{D}_{3} \text { (PDB ID: 3PBL) are obtained from Protein Data Bank. In-silico docking analysis was } \\
\text { performed by using Molegro virtual docker (MVD). The phytoconstituents with least MolDock score and } \\
\text { hydrogen bond interactions shows maximum affinity for the target. The antipsychotic activity of the } \\
\text { phytoconstituents of medicinal plants is analyzed by docking score and binding energy. The phytoconstituents } \\
\text { from Morinda citrifolia exhibited the binding pattern to that of the standard drugs exhibiting antipsychotic } \\
\text { activity by inhibiting } \mathrm{D}_{2} \text { and } \mathrm{D}_{3} \text { dopamine receptors. }\end{array}$} \\
\hline Received on: 04/11/2016 & \\
\hline Accepted on: 20/01/2017 & \\
\hline Available online: 30/04/2017 & \\
\hline Key words: & \\
\hline $\begin{array}{l}\text { GC-MS, phytoconstituents, } \\
\text { Morinda citrifolia, Noni, } \\
\text { docking, antipsychotic } \\
\text { activity. }\end{array}$ & \\
\hline
\end{tabular}

\section{INTRODUCTION}

Schizophrenia is considered to be a neurodevelopmental disease and is suggested to be associated with excessive stimulation of dopamine $D_{2}$ receptors in the associative striatum, with a lack of stimulation of dopamine $D_{1}$ receptors in prefrontal cortex however the primary process connected with this disease remains indecisive (Laruelle, 2014). The unexpected discovery in the 1950s, that confirmed that chlorpromazine a phenothiazine derivative, was an effective antipsychotic, is often said to be one of the greatest advances of $20^{\text {th }}$ century medicine and dramatically changed the treatment and outcome of schizophrenia. It set in motion a wave of drug discovery that resulted in 15 approved antipsychotics in United

\footnotetext{
* Corresponding Author

Srikanth Jeyabalan, Department of Pharmacology, Faculty of Pharmacy, Sri Ramachandra University, Porur, Chennai - 600 116, Tamil Nadu, India.Email: srikanthcologist@gmail.com
}

States and 40 globally (Gopalakrishna et al., 2016). Since then, antipsychotic drugs have been the drugs of choice for the treatment of schizophrenia, and about 60 different antipsychotics have been introduced. Although pharmacologically these drugs show large differences, all antipsychotics appear to reduce the positive symptoms of schizophrenia, but unfortunately, have little or no effect on the negative symptoms or the cognitive deficits (Sánchez and Ellenbroek, 2016). Drugs acting on dopamine receptors $\left(\mathrm{D}_{1}\right.$, $D_{2}, D_{3}, D_{4}$, and $D_{5}$ ) are significant tools for the management of several neuropsychiatric disorders including schizophrenia, bipolar disorder, depression and Parkinson's disease (Beaulieu et al., 2015). The introduction of the benzodiazepine, clozapine, opened the period of "atypical" antipsychotic drugs, which show a reduced potential to persuade extrapyramidal symptoms (EPS), an augmented effectiveness for the negative symptoms of schizophrenia, no rise of prolactin after persistent use (except risperidone), and effectiveness in some patients formerly regarded as treatment-refractory (Shen, 1999). 
Further there is increasingly strong evidence that $D_{3}$ receptor antagonists could be effective antipsychotic agents and could also be involved in behavioural sensitization, with potential efficacy in the treatment of drug abuse (Maramai et al., 2016).

Morinda citrifolia Linn belongs to the family Rubiaceae and habituated to Sub-himalayan tracts, darjeeling, konkan and the andamans. The Indian Mulberry is commonly known as ashyuka, akshi and atchy in ayurvedic and nunaa, togaru in siddha (Khare, 2008).

Morinda citrifolia (Noni) has been used for centuries to cure or prevent varieties of illnesses by traditional medical practitioners in Hawaii and Polynesia. It contains phytochemicals that own antibacterial, antiviral, antifungal, antitumor, anthelminthic, analgesic, hypotensive, anti-inflammatory and immune enhancing effects. A complete review on Morinda citrifolia was performed by Assi et al. was carried out in 2016 which described the antimicrobial and antiseptic activity, antifungal activity, antioxidant activity, anti-inflammatory activity, anti-arthritic activity, anti-cancer activity, antidiabetic activity, wound healing activity, memory enhancing activity, anxiolytic and sedative activity, analgesic activity, gastric ulcer healing activity, antiemetic activity, gout and hyperuricemia healing activity, immunity enhancing activity, anti-viral activity, anti-parasitic activity, anti-tuberculosis activity, osteoporotic and otoscopic enhancer. These activities were carried out to the extent of in-vitro, in-vivo and clinical trial stages (Assi et al., 2016).

In our previous study we reported the antiulcer (Muralidharan and Srikanth, 2010) and antiepileptic activity of Morinda citrifolia (Srikanth and Muralidharan, 2009). Previous study by Pandy et al. demonstrated the antipsychotic-like activity of noni (Morinda citrifolia Linn.) in mice (Pandy et al., 2012). The present study is focused to identify the phytoconstituents in Morinda citrifolia which may be responsible for antipsychotic activity.

\section{EXPERIMENTAL}

\section{Plant material and Sample preparation}

The full spectrum standardised extract of Morinda citrifolia fruit was obtained from Amsar Goa Pvt Ltd, Goa. The plant was authenticated by Dr Laxmi Morajkar, Head Ayurveda Division (Voucher specimen Number: AGPL/039/13-14). The lyophilized powder was made soluble in ethanol and the GC-MS analysis of the compound was performed. $1.0 \mathrm{~g}$ of the lyophilized powdered Morinda citrifolia was soaked in $10 \mathrm{ml}$ of ethanol for 12 hrs. The extract is vortex and filtered. $1.0 \mu \mathrm{l}$ of this filtered solution was injected for GC-MS analysis.

\section{GC-MS analysis}

GC-MS analysis of the extract of Morinda citrifolia was performed using a Thermo Scientific TRACE Ultra Gas Chromatograph interfaced to a TSQ Quantum Ultra ${ }^{\mathrm{TM}}$ Triple Quadrupole Mass Spectrometer (GC-MS) equipped with Trace GOLD TG-5MS GC Columns (5\% diphenyl 95\% dimethyl polysiloxae) fused a capillary column $(30 \times 0.25 \mu \mathrm{m}$ ID $\times 0.25 \mu \mathrm{m}$ df). Helium (99.999\%) was used as the carrier gas with a flow rate of $1 \mathrm{ml} / \mathrm{min}$ in the split less mode. An aliquot of $1 \mu \mathrm{l}$ of ethanol solution of the sample was injected into the column. The oven temperature was programmed from $80{ }^{\circ} \mathrm{C}$ (isothermal for 0.0 min), with an increase of $5.0^{\circ} \mathrm{C} / \mathrm{min}$, to $300^{\circ} \mathrm{C}$ ending with an isothermal at $300^{\circ} \mathrm{C}$ for $2.0 \mathrm{~min}$. The injector and auxiliary temperatures were set at $300^{\circ} \mathrm{C}$ and $280^{\circ} \mathrm{C}$ respectively. Ion source temperature was maintained at $225^{\circ} \mathrm{C}$. The mass spectrum of compounds in samples was obtained by electron ionization at 70 $\mathrm{eV}$ and the detector was operated in scan mode from $35-500 \mathrm{~m} / \mathrm{z}$. The total running time was 46 minutes. The relative percentage amount of each component was calculated by comparing its average peak area to the total areas (Ezhilan and Neelamegam, 2012).

\section{Identification of Phytoconstituents}

Interpretation on mass-spectrum GC-MS was conducted using the database of National Institute Standard and Technology (NIST) library having more than 62,000 patterns Identification was based on the molecular structure, molecular mass and calculated fragments along with the probability (Linstrom and Mallard, 2016).

\section{Molecular docking study \\ Preparation of ligand}

The 3D structures of the phytoconstituents from Morinda citrifolia identified in GC-MS analysis and selected for docking study were obtained from PubChem compound database (Kim et al., 2016) and saved in .mol format. The standard drugs typical antipsychotic (Chlorpromazine, Haloperidol) and atypical antipsychotic drugs (Amisulpride, Aripiprazole, Clozapine, Risperidone, Paliperidone and Pimozide) were obtained from Drugbank database (Wishart et al., 2006) and saved in .mol format. The ligands both the phytoconstituents and the standard drug were imported to the workspace of Molegro virtual docker (MVD) (Thomsen and Christensen, 2006) and prepared for further docking procedure. The docking scores and docking pattern of the active constituents are compared against the standard drugs.

\section{Preparation of protein (receptors)}

The targets for docking studies were selected as $\mathrm{D}_{2}$ and $\mathrm{D}_{3}$ receptors. The $3 \mathrm{D}$ protein structures of the targets dopamine receptor $\mathrm{D}_{2}$ (PDB ID: 5AER) (Pandalaneni et al., 2015) and dopamine receptor $\mathrm{D}_{3}$ (PDB ID: 3PBL) (Chien et al., 2010) are obtained from Protein Data Bank (Berman et al., 2000). It is well known that PDB files often have poor or missing assignments of explicit hydrogen and the PDB file format cannot accommodate bond order information.

Therefore, proper bonds, bond orders, hybridization and charges were assigned using the MVD. The potential binding sites of both the targets were calculated using the built-in cavity detection algorithm implemented in MVD. The search space of the simulation exploited in the docking studies was studied as a subset 
region of 25.0 Angstroms around the active side cleft. The water molecules are also taken in to consideration and the replaceable water molecules were given a score of 0.50 .

The protein surface was created using create surface on the protein in the workspace explorer. In create surface the surface target for PDB ID: 5AER and 3PBL was set as molecular surface with a resolution of $0.7 \AA$ and probe radius of $1.00 \AA$. The surface type colouring was set as electrostatic. The cavities are detected in the protein molecule. Under general settings the molecular surface is set as expanded vanderwaal with maximum number of cavities as 5 . The active site of the receptor was identified with the built in software in MVD.

\section{Parameters for Scoring Function MolDock Score}

The MolDock scoring function (MolDock Score) used by MVD is derived from the PLP (piecewise linear potential) scoring functions originally proposed by Gehlhaar et al. and later extended by Yang et al. (Gehlhaar et al., 1995; Gehlhaar et al., 1998; Yang and Chen, 2004) . The MolDock scoring function further improves these scoring functions with a new hydrogen bonding term and new charge schemes. The docking scoring function, $\mathrm{E}_{\text {score }}$, is defined by the following energy terms: $E_{\text {score }}=E_{\text {inter }}+E_{\text {intra }}$ Where $E_{\text {inter }}$ is the ligand-protein interaction energy, $E_{\text {intra }}$ is the internal energy of the ligand

\section{RESULTS AND DISCUSSION \\ GC-MS analysis}

GC-MS chromatogram of the standardised extract of Morinda citrifolia [Figure 1] showed 16 major peaks indicating the presence of 16 phytochemical constituents. On comparison of the mass spectra of the constituents with the NIST library, the 16 phytocompounds were characterized and identified. The Spectrum of the unknown component was compared with the spectrum of the component stored in the NIST library and the results are tabulated [Table 1].

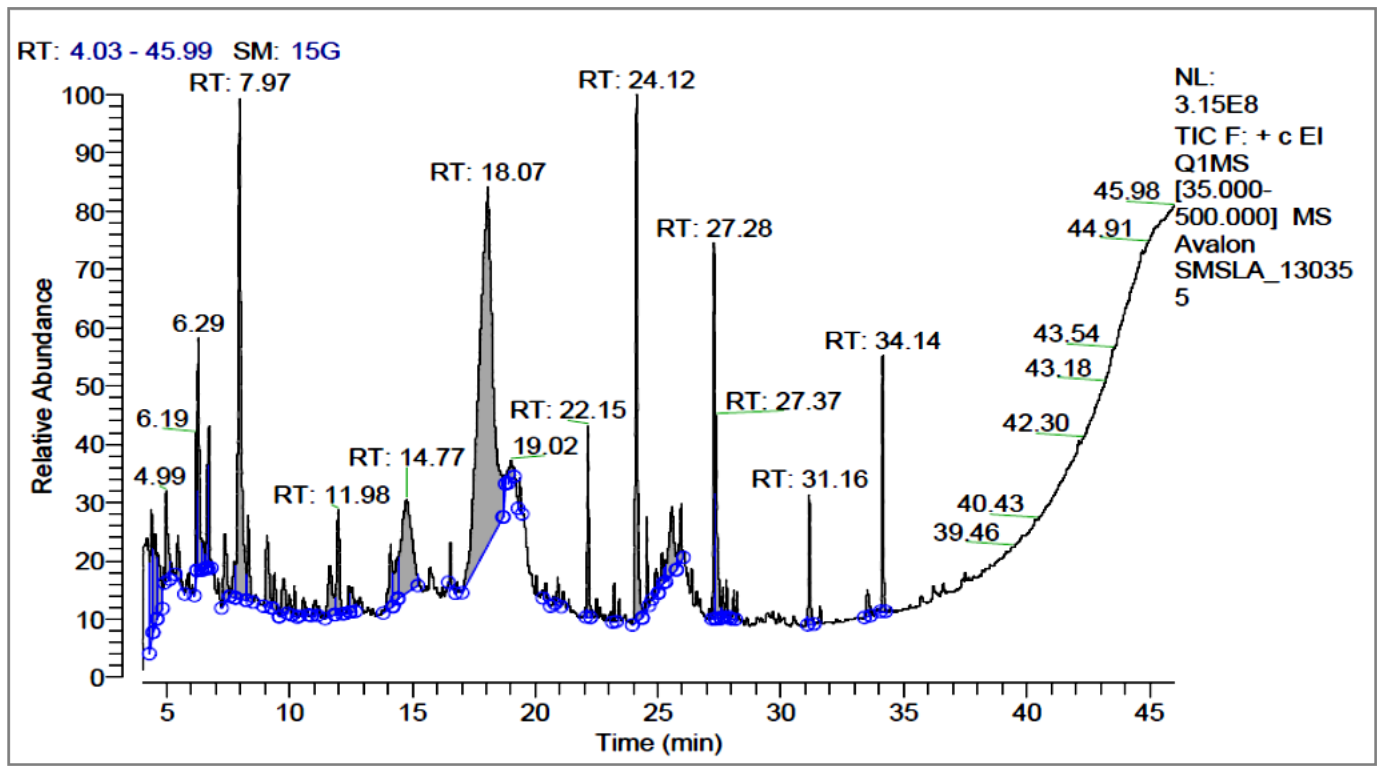

Fig. 1: GC-MS chromtogram of Morinda citrifolia fruit extract.

Table 1: GC-MS analysis of phytoconstituents of Morinda citrifolia fruit extract obtained from NIST library based on the molecular weight and molecular formula.

\begin{tabular}{lccccc}
\hline S. No. & RT & Peak area (\%) & Compound name & Molecular weight (g/mol) & Molecular formula \\
\hline 1. & 6.19 & 0.96 & Hexanoic acid & 186 & $\mathrm{C}_{10} \mathrm{H}_{18} \mathrm{O}_{3}$ \\
2. & 6.67 & 0.79 & Octanoic acid & 144 & $\mathrm{C}_{8} \mathrm{H}_{16} \mathrm{O}_{2}$ \\
3. & 11.08 & 0.31 & Beta-carotene & 536.87 & $\mathrm{C}_{40} \mathrm{H}_{56}$ \\
4. & 14.4 & 1.01 & Scopoletin & 192.16 & $\mathrm{C}_{10} \mathrm{H}_{8} \mathrm{O}_{4}$ \\
5. & 16.55 & 0.39 & Ascorbic-acid & 176.12 & $\mathrm{C}_{6} \mathrm{H}_{8} \mathrm{O}_{6}$ \\
6. & 18.07 & 30.35 & Butanoic acid & 200 & $\mathrm{C}_{12} \mathrm{H}_{24} \mathrm{O}_{2}$ \\
7. & 19.37 & 0.29 & Beta-sitosterol & 414.71 & $\mathrm{C}_{29} \mathrm{H}_{50} \mathrm{O}$ \\
8. & 20.41 & 0.3 & Morindin & 564.49 & $\mathrm{C}_{26} \mathrm{H}_{28} \mathrm{O}_{14}$ \\
9. & 20.93 & 0.35 & Morindone & 270.24 & $\mathrm{C}_{15} \mathrm{H}_{10} \mathrm{O}_{5}$ \\
10. & 22.15 & 1.81 & $5,7-$ Dihydroxy-4-methylcoumarin & 27 & $\mathrm{C}_{10} \mathrm{H}_{8} \mathrm{O}_{4}$ \\
11. & 24.12 & 7.08 & Dibutyl phthalate & 278 & $\mathrm{C}_{16} \mathrm{H}_{22} \mathrm{O}_{4}$ \\
12. & 27.28 & 3.31 & Octadecadienoic acid & 280 & $\mathrm{C}_{18} \mathrm{H}_{32} \mathrm{O}_{2}$ \\
13. & 27.37 & 2.46 & Oleic Acid & 282 & $\mathrm{C}_{18} \mathrm{H}_{34} \mathrm{O}_{2}$ \\
14. & 28.08 & 0.26 & Alizarin & 240.21 & $\mathrm{C}_{14} \mathrm{H}_{8} \mathrm{O}_{4}$ \\
15. & 31.16 & 1.22 & 9-Octadecenamide & 281 & $\mathrm{C}_{18} \mathrm{H}_{35} \mathrm{NO}$ \\
16. & 33.51 & 0.43 & Rutin & 610.52 & $\mathrm{C}_{27} \mathrm{H}_{30} \mathrm{O}_{16}$ \\
\hline
\end{tabular}


Table 2: Molecular docking analysis of phytoconstituents from Morinda citrifolia fruit extract and standard drugs along with their target (PDB ID: 5AER) amino acid residues of dopamine receptor $\left(\mathrm{D}_{2}\right)$ arranged with ranking based on hydrogen bond interaction.

\begin{tabular}{|c|c|c|c|c|}
\hline Pose & $\begin{array}{l}\text { MolDock } \\
\text { Score }\end{array}$ & HBond & $\begin{array}{c}\text { Protein } \\
\text { molecule } \\
\text { chain }\end{array}$ & Target amino acid involved in interaction with the ligand (Including hydrogen bond interaction) \\
\hline [00]Ascorbic-acid & -69.32 & -8.39 & A chain & Asn 70, Asn 12, Asp 73, Asp 109, Asp 111, Glu 74, Leu 110, Lys 76, Lys 106, Val 71 \\
\hline [00]Rutin & -120.52 & -7.56 & A chain & $\begin{array}{l}\text { Arg 102, Asn 70, Asn 112, Asp 73, Asp 109, Glu 74, Gly 114, Leu 166, Lys 76, Lys 106, Phe 72, Phe 105, Val 71, } \\
\text { Val 91 }\end{array}$ \\
\hline [00]Morindin & -80.37 & -5.04 & A chain & Asn 70, Asn 112, Asp 73, Asp 109, Asp 111, Asp 113, Glu 74, Gly 114, Leu 110, Lys 76, Lys 106, Phe 105, Val 71 \\
\hline [00]Alizarin & -67.07 & -4.59 & A chain & Asn 70, Asn 112, Asp 73, Asp 109, Asp 111, Glu 74, Leu 110, Lys 76, Lys 106, Val 71 \\
\hline [00]Paliperidone & -114.21 & -4.52 & A chain & $\begin{array}{l}\text { Asn 70, Asn 112, Asn 119, Asp 73, Asp 109, Asp 111, Asp 123, Glu 74, Glu 120, Leu 110, Lys 76, Lys 106, Phe 67, } \\
\text { Val } 71\end{array}$ \\
\hline [00]Haloperidol & -91.33 & -3.23 & A chain & Asn 70, Asn 112, Asp 73, Asp 109, Asp 111, Glu 74, Leu 110, Lys 76, Lys 106, Val 71 \\
\hline [00]Scopoletin & -65.01 & -2.5 & A chain & Asn 70, Asn 112, Asp 73, Asp 109, Asp 111, Glu 74, Leu 110, Lys 76, Lys 106, Val 71 \\
\hline [00]Beta-sitosterol & -92.50 & -2.5 & A chain & Arg 102, Asn 70, Asn 112, Asp 73, Gln 87, Glu 74, Glu 99, Lys 76, Lys 106, Phe 72, Tyr 21, Val 71, Val 91 \\
\hline [00]Chlorpromazine & -83.47 & -2.11 & A chain & $\begin{array}{l}\text { Ala } 88, \text { Arg 102, Asn 70, Asn 112, Asp 73, Gln 87, Glu 74, Glu 81, Glu 84, Glu 99, Lys 9, Lys 19, Lys 76, Lys 100, } \\
\text { Lys 106, Phe 72, Trp 103, Val 71, Val 91 }\end{array}$ \\
\hline [00]Clozapine & -63.74 & -1.48 & A chain & Asn 70, Asn 112, Asp 73, Asp 109, Asp 111, Glu 74, Leu 110, Lys 76, Lys 106, Phe 72, Val 71 \\
\hline [00]Aripiprazole & -115.04 & -1.19 & A chain & $\begin{array}{c}\text { Arg 102, Asn 70, Asn 75, Asn112, Asp 73, Asp 109, Asp 111, Glu 74, Gly 114, Leu 110, Leu 166, Lys 76, Lys 106, } \\
\text { Phe 72, Phe 105, Trp 103, Val 71 }\end{array}$ \\
\hline [00]Risperidone & -96.34 & -0.35 & A chain & $\begin{array}{l}\text { Asn 70, Asn 75, Asn 112, Asp 73, Asp 109, Asp 111, Asp 123, Glu 74, Glu 120,Leu 110,Lys 76,Lys 106, Phe 72, Val } \\
71\end{array}$ \\
\hline [00]Pimozide & -116.13 & 0 & A chain & $\begin{array}{l}\text { Arg 102, Asn 70, Asn 112, Asp 73, Gln 87, Glu 74, Glu 99, Leu 166, Lys 76, Lys 106, Phe 72, Phe 105, Trp 103, Val } \\
\text { 71, Val } 91\end{array}$ \\
\hline [00]Beta-carotene & -112.21 & 0 & A chain & $\begin{array}{l}\text { Asn70, Asn112, Asp109, Asp111, Asp123, Gln87, Glu74, Glu99, Leu110, Lys19, Lys76, Lys106, Phe67, Val71, } \\
\text { Val91 }\end{array}$ \\
\hline [00]Amisulpride & -101.66 & 0 & A chain & $\begin{array}{l}\text { Arg 102, Asn 70, Asn 112, Asp 73, Asp 109, Glu 74, Gly 114, Leu 166, Lys 76, Lys 106, Phe 72, Phe 10, Trp 103, } \\
\text { Val 71 }\end{array}$ \\
\hline [00]Morindone & -61.11 & 0 & A chain & Asn 70, Asn 112, Asp 73, Asp 109, Asp 111, Glu 74, Leu 110, Lys 76, Lys 106, Phe 72, Val 71 \\
\hline
\end{tabular}

Table 3: Molecular docking analysis of phytoconstituents from Morinda citrifolia fruit extract and standard drugs along with their target (PDB ID: 3PBL) amino acid residues of dopamine receptor $\left(\mathrm{D}_{3}\right)$ arranged with ranking based on hydrogen bond interaction.

\begin{tabular}{|c|c|c|c|c|}
\hline \multirow{2}{*}{ Name } & \multirow{2}{*}{$\begin{array}{l}\text { MolDock } \\
\text { Score }\end{array}$} & \multirow{2}{*}{ HBond } & \multicolumn{2}{|c|}{ Target amino acid involved in interaction with the ligand (Including hydrogen bond interaction) } \\
\hline & & & A chain & B chain \\
\hline [00]Morindone & -66.81 & -10.36 & $\begin{array}{l}\text { Arg 1008, Asp 1010, Glu 1005, Glu 1011, Gly 1012, His } 137 \text {, } \\
\text { Ile 1009, Lys 221, Met 134, Pro 135, Val 133, Val } 136\end{array}$ & \\
\hline [00]Paliperidone & -121.16 & -10.10 & Arg 1008, Asp 1061, Leu 1015, Lys 1060, Met 134, Thr 1059 & $\begin{array}{l}\text { Asn } 185 \text {, Asn } 352 \text {, Cys } 355 \text {, Gln } 356 \text {, Gly } 176 \text {, His } 359 \text {, Pro } \\
\text { 186, Ser } 184 \text {, Thr } 174, \text { Thr } 175, \text { Thr } 353 \text {, Thr } 357 \text {, Val } 360\end{array}$ \\
\hline [00]Alizarin & -72.65 & -9.31 & $\begin{array}{l}\text { Arg 1008, Asp 1010, Glu 1005, Glu 1011, Gly 1012, His } 137 \text {, } \\
\text { Ile 1009, Lys 221, Met 134, Pro 135, Val 133, Val } 136\end{array}$ & \\
\hline [00]Morindin & -63.61 & -8.26 & Leu 1015 & $\begin{array}{l}\text { Asn 352, Gln 356, Gly 93, Gly 94, His 354, His 359, Pro } 186 \\
\text { Pro 362, Ser 184, Ser 361, Ser 366, Thr353, Tyr 365, Val } 360\end{array}$ \\
\hline [00]Ascorbic-acid & -68.69 & -7.41 & Asp 1061, Lys 1060, Thr 1059 & $\begin{array}{c}\text { Asn 352, Cys 355, Cys 358, Gln 356, His 359, Leu 351, Thr } \\
\text { 357, Val 360 }\end{array}$ \\
\hline [00]Scopoletin & -70.75 & -5.03 & $\begin{array}{c}\text { Arg 1008, Glu 1005, His 137, Ile 1009, Lys 221, Met 134, Pro } \\
135, \text { Val 133, Val } 136\end{array}$ & \\
\hline [00]Aripiprazole & -97.04 & -4.32 & $\begin{array}{c}\text { Arg 149, Arg 1008, Asp 127, Asp 1010, Gly 141, His } 137 \text {, His } \\
\text { 140, Ile 1009, Met 134, Pro 135, Thr 130, Thr 142, Tyr 138, Val } \\
\text { 133, Val } 136\end{array}$ & Asn 173 , Gly 171 , Phe 170 , Phe 172, Thr 174 \\
\hline [00]Rutin & -143.02 & -3.67 & $\begin{array}{c}\text { Arg 1008, Arg 1014, Glu 1011, Gly 1012, His 137, His 140, Ile } \\
\text { 1009, Leu 1013, Met 134, Tyr 1018, Val } 136\end{array}$ & $\begin{array}{l}\text { Arg 100, Asn 173, Asp 177, Gly 176, Pro 178, Thr 174, Thr } \\
175\end{array}$ \\
\hline [00]Amisulpride & -118.18 & -2.41 & Arg 1008, Arg 1014, Leu 1013, Leu 1015, Lys 1016, Lys 1060 & $\begin{array}{l}\text { Asn } 185 \text {, Asn 352, Asp 177, Gly 176, His 349, Ile 183, Ser } \\
\text { 182, Ser 184, Thr 174, Thr 175, Thr 353, Tyr 365, Val180 }\end{array}$ \\
\hline [00]Clozapine & -102.58 & -0.52 & $\begin{array}{c}\text { Arg 1008, Arg 1148, Asn 1144, Asp 1010, Glu 1011, Gly 1012, } \\
\text { His 137, His 140, Ile 1009, Leu 1013, Lys 221, Met 134, Pro } \\
\text { 135, Tyr 1161, Val 133, Val 136 }\end{array}$ & Asp 177, Gly 176, Pro 178 \\
\hline [00]Pimozide & -103.77 & -0.16 & $\begin{array}{l}\text { Arg 1008, Asp 1061, Leu 1013, Leu 1015, Lys 1060, Met 134, } \\
\text { Thr } 1059\end{array}$ & $\begin{array}{c}\text { Asn } 185 \text {, Asn } 352 \text {, Gln } 356 \text {, Gly } 176 \text {, His } 354 \text {, His } 359 \text {, Pro } \\
\text { 186, Ser } 184 \text {, Thr } 174 \text {, Thr } 175 \text {, Thr } 353 \text {, Thr } 357\end{array}$ \\
\hline$[00]$ Risperidone & -131.53 & 0 & $\begin{array}{c}\text { Arg 1008, Arg 1014, Asp 1061, Leu 1013, Leu 1015, Lys 1060, } \\
\text { Thr } 1059\end{array}$ & $\begin{array}{c}\text { Asn 352, Asp 177, Cys 355, Cys 358, Gln 356, Gly 176, His } \\
\text { 359, Leu 351, Ser 182, Ser 184, Thr 175, Thr 353, Thr 357, } \\
\text { Val 180, Val } 360\end{array}$ \\
\hline$[00]$ Beta-carotene & -128.38 & 0 & $\begin{array}{c}\text { Arg 218, Arg 219, Arg 220, Arg 1008, Arg 1014, Asp 1010, Asp } \\
\text { 1020, Gln 217, Glu 1005, Glu 1011, Gly 1012, His 137, Ile } \\
\text { 1009, Lys 221, Lys 1019, Met 134, Pro 135, Thr 1021, Tyr } \\
\text { 1018, Tyr 1161, Val 132, Val 133, Val 136, Val 214 }\end{array}$ & Gly 176 , Pro 178 \\
\hline [00]Haloperidol & -109.10 & 0 & $\begin{array}{c}\text { Arg 1008, Glu 1005, His 137, Ile 1009, Lys 221, Met 134, Pro } \\
135 \text {, Tyr 1161, Val 132, Val 133, Val } 136\end{array}$ & $\begin{array}{l}\text { Arg 100, Asn 173, Asp 177, Gly 176, Pro 178, Thr 174, Thr } \\
175\end{array}$ \\
\hline$[00]$ Beta-sitosterol & -109.10 & 0 & Lys 1060, Thr 1059 & $\begin{array}{c}\text { Asn 352, Cys 355, Cys 358, Gln 356, His 354, His 359, Leu } \\
\text { 351, Pro 186, Pro 362, Thr 353, Thr 357, Val } 360\end{array}$ \\
\hline$[00]$ Chlorpromazine & -83.27 & 0 & Arg 1008, Arg 1014, Leu 1013, Leu 1015, Lys 1016, Lys 1060 & $\begin{array}{c}\text { Arg 100, Asn 352, Asp 177, Gly 176, His 349, Ile 183, Ser } \\
\text { 182, Ser 184, Thr 175, Thr 353, Val } 180\end{array}$ \\
\hline
\end{tabular}




\section{Molecular Docking studies}

The phytoconstituents identified in GC-MS analysis and selected for docking studies include alizarin, ascorbic-acid, betacarotene, beta-sitosterol, morindin, morindone, rutin, and scopoletin. The protein selected for docking study includes dopamine receptor $\mathrm{D}_{2}$ with PDB ID: 5AER which consists of three chains. A chain consists of 183 amino acid residues whereas B and $\mathrm{C}$ chain consists of 14 amino acid residues. The protein $\mathrm{D}_{3}$ dopamine receptor with PDB ID: 3PBL consists of 2 chains with an amino acid residue of 432 and 423 respectively in A and B chain.

Molecular docking studies were performed and the docking results are tabulated [Table 2 and 3]. The molecular interactions of phytoconstituents along with $\mathrm{D}_{2}$ and $\mathrm{D}_{3}$ receptor were compared with that of the standard typical antipsychotic (chlorpromazine, haloperidol) and atypical antipsychotic drugs (amisulpride, aripiprazole, clozapine, risperidone, paliperidone and pimozide). The docking simulation with $\mathrm{D}_{2}$ Dopamine receptor with PDB ID: 5AER revealed all the interactions involved only the A chain for both the phytoconstituents and standard drugs. The least MolDock score is simulated by rutin followed by pimozide and aripiprazole with a value of $-120.52,-116.13$ and -115.04 respectively. The maximum hydrogen bond interaction was rendered by the phytoconstituents ascorbic-acid, rutin, morindin, and alizarin with a value of $-8.39,-7.56,-5.04$ and -4.59 respectively followed by the standard drugs paliperidone and haloperidol with an interaction of -4.52 and -3.23 .

The docking simulation with $\mathrm{D}_{3}$ Dopamine receptor with PDB ID: 3PBL revealed all the interactions involved both A chain and $\mathrm{B}$ chain except for the phytoconstituents morindone, alizarin and scopoletin which involved interaction with amino acid residues only of the A chain. The least MolDock score is simulated by rutin with a MolDock score of -143.02 followed by risperidone with a MolDock score of -131.53 . The maximum hydrogen bond interaction was rendered by the phytoconstituent morindone with a value of -10.36 followed by the standard drug paliperidone with a hydrogen bond interaction value of -10.10 .

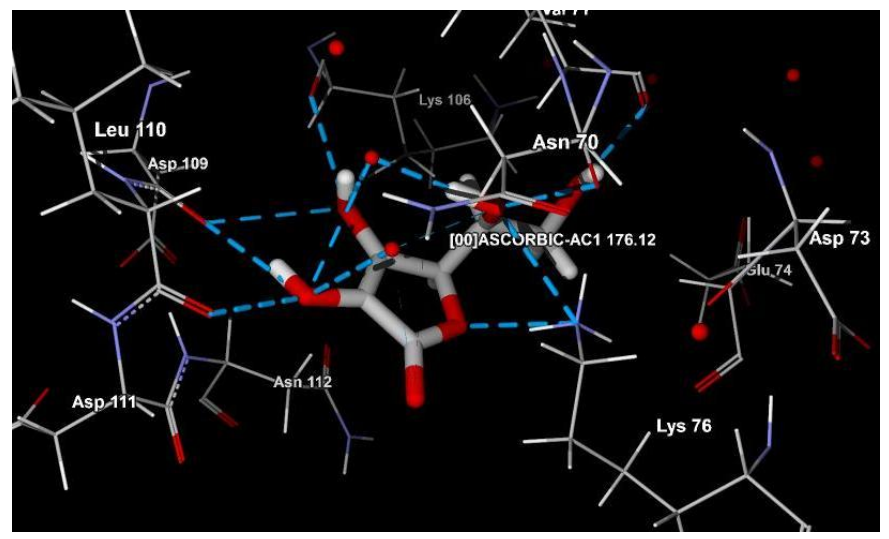

Fig. 2: Hydrogen bond interaction of ascorbic acid along with the amino acid residues of Dopamine $D_{2}$ receptor in A chain. The hydrogen bonds are represented in blue colour lines. The docked ascorbic acid is represented in stick model along with the molecular weight.
The docking pattern of ascorbic acid was compared with that of paliperidone on $\mathrm{D}_{2}$ dopamine receptor (PDB ID: 5AER) and it was observed that the standard drug was able to bind to more amino acid residues than ascorbic acid. The drug paliperidone was able to bind to amino acid residues Asn 70, Asn 12, Asp 73, Asp 109, Asp 111, Glu 74, Leu 110, Lys 76, Lys 106, Val 71 as ascorbic acid and in addition it was bonded to Asn 112, Asn 119, Asp 123, Glu 120 and Phe 67 as represented in figure 2 and 3. This was reflected in the MolDock score with a value of 114.21 for Paliperidone whereas the MolDock score of ascorbic acid was found to be -69.32 .

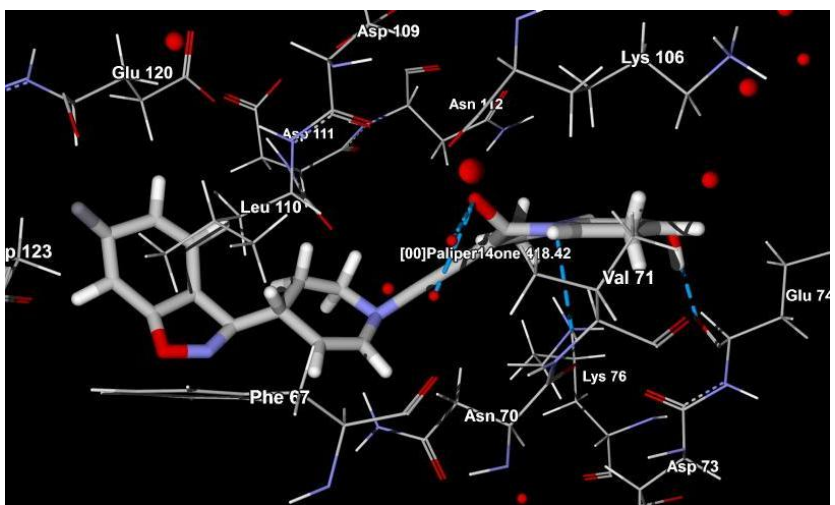

Fig. 3: Hydrogen bond interaction of standard drug paliperidone along with the amino acid residues of Dopamine D2 receptor in A chain. The hydrogen bonds are represented in blue colour lines. The docked paliperidone is represented in stick model with the molecular weight.

The docking pattern of morindone was compared with that of paliperidone on $\mathrm{D}_{3}$ dopamine receptor (PDB ID: 3PBL) and it was observed that the standard drug was able to bind amino acid residues in both $\mathrm{A}$ and $\mathrm{B}$ chain of the receptor. The MolDock score and hydrogen bond energy for morindone was found to be 66.81 and -10.36 and for paliperidone it was found to be -121.16 and -10.10 respectively. This is represented in figure 3 and 4 . The docking analysis of standard drugs based on their MolDcok score on the target $\mathrm{D}_{2}$ dopamine receptor revealed the following ranking with pimozide (-116.13) followed by aripiprazole (-115.04), paliperidone (-114.21), amisulpride (-101.66), risperidone (96.34), haloperidol (-91.33), chlorpromazine (-83.47), clozapine (63.74).The docking analysis of standard drugs based on their MolDcok score on the target $\mathrm{D}_{3}$ dopmaine receptor revealed the following ranking with risperidone (-131.53) followed by paliperidone (-121.16), amisulpride (-118.18), haloperidol (109.10), pimozide (-103.77), clozapine (-102.58), aripiprazole $(-97.04)$ and chlorpromazine $(-83.27)$. This revealed that the scoring function reflected the evolution of dopamine receptor antagonist from the first generation antipsychotics and their affinity towards the dopamine receptor.

An ideal psychotropic drug should cure or lessen the pathogenic mechanisms of the disorder that is being treated, and be without unwanted effects (Lingjaerde et al., 1987). No such ideal drugs have yet been developed. All known psychotropic drugs may cause unwanted effects (Owens, 2014). Antipsychotic 
drugs are best classified as typical or atypical. The difference is based solely on their ability to cause extrapyramidal side effects, including tardive dyskinesia (Meltzer, 2013). The development of $\mathrm{D}_{3}$-selective antagonists should have the capacity to bind to orthosteric site as well as a secondary binding pocket (Furman et al., 2015). The important clinical application and potential for selective Dopamine $\mathrm{D}_{3}$ receptor antagonists lies in the decrease of drug-induced motivation. The selectivity of these antagonists jointly with reduced lipophilicity (minimizing unspecific binding), augmented brain penetration and enhanced physico-chemical profile are all key factors for clinical efficacy and safety (Micheli and Heidbreder, 2013).

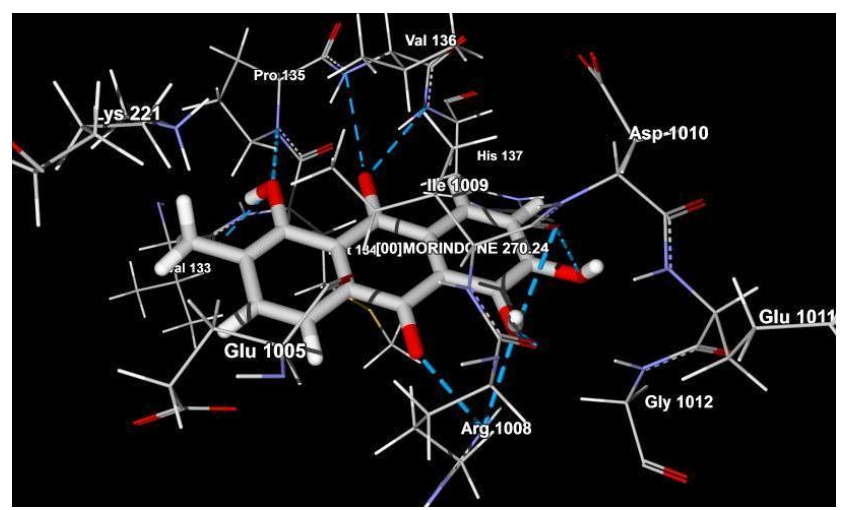

Fig. 4: Hydrogen bond interaction of morindone along with the amino acid residues of Dopamine $\mathrm{D}_{3}$ receptor in $\mathrm{A}$ chain. The hydrogen bonds are represented in blue colour lines. The docked ascorbic acid is represented in stick model along with the molecular weight.

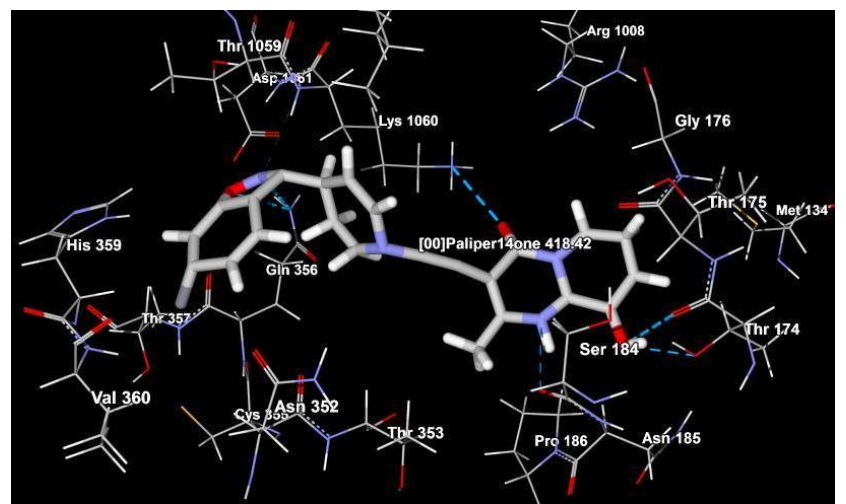

Fig. 5: Hydrogen bond interaction of standard drug paliperidone along with the amino acid residues of Dopamine $\mathrm{D}_{3}$ receptor in both $\mathrm{A}$ and $\mathrm{B}$ chain. The hydrogen bonds are represented in blue colour lines. The docked paliperidone is represented in stick model with the molecular weight.

Almost all available antipsychotic agents are dopamine $\mathrm{D}_{2}, \mathrm{D}_{3}$, and/or $\mathrm{D}_{4}$ receptor antagonists (Dunlop and Brandon, 2015). Three partial agonist compounds have now been permitted for acute psychosis related with schizophrenia by the US Food and Drug Administration (FDA): aripiprazole, brexpiprazole, and cariprazine (Mailman and Murthy, 2010; Roberts et al., 2016).

Herbal treatments have a role in psychiatric medicine and a number of them have been reported safe and effective in the literature (Stradford et al., 2012). The alternative medicine serves as potential treatment with less unwanted effects. The phytoconstituents from Morinda citrifolia has provided maximum affinity to the target receptor to that of the standard drugs. Further studies may be carried out to isolate the phytoconstituents from Morinda citrifolia and perform radio ligand binding assay against the dopamine receptors to confirm its anti psychotic activity

\section{ACKNOWLEDGEMENT}

The authors sincerely thank the management of Sri Ramachandra University for providing us with all the facilities for the successful completion of the project.

Sources of Funding: This project is funded by Growth and Advancement Towards Excellence (GATE) Research Grants to Young Faculty of Sri Ramachandra University and Career Award for Young Teachers (CAYT) - All India Council for Technical Education (AICTE), New Delhi

Conflict of Interest: Authors' declare no conflict of interest.

\section{REFERENCES}

Assi RA, Darwis Y, Abdulbaqi IM, Vuanghao L, Laghari MH. Morinda citrifolia (Noni): A comprehensive review on its industrial uses, pharmacological activities, and clinical trials. Arabian Journal of Chemistry. 2015 Jun 24. doi.org/10.1016/j.arabjc.2015.06.018

Beaulieu JM, Espinoza S, Gainetdinov RR. Dopamine receptors-IUPHAR review 13. British journal of pharmacology. 2015 $1 ; 172(1): 1-23$.

Berman HM., Westbrook J, Feng Z, Gilliland G, Bhat TN, Weissig H.M., Shindyalov I.N, Bourne PE. 2000. The Protein Data Bank. Nucleic Acids Research, 28: 235-242.

Dunlop J, Brandon NJ. Schizophrenia drug discovery and development in an evolving era: are new drug targets fulfilling expectations? J Psychopharmacol. 2015; 29(2):230-238.

Ezhilan BP, Neelamegam R. GC-MS analysis of phytocomponents in the ethanol extract of Polygonum chinense $\mathrm{L}$. Pharmacognosy Research. 2012;4(1):11.

Furman CA, Roof RA, Moritz AE, Miller BN, Doyle TB, Free RB, Banala AK, Paul NM, Kumar V, Sibley CD, Newman AH. Investigation of the binding and functional properties of extended length $\mathrm{D}$ 3 dopamine receptor-selective antagonists. European Neuropsychopharmacology. 2015; 25(9):1448-61.

Gehlhaar DK, Bouzida D, Rejto PA, Eds: Fully automated and rapid flexible docking of inhibitors covalently bound to serine proteases. In Proceedings of the Seventh International Conference on Evolutionary Programming: 25-27 March 1998; San Diego Edited by: William Porto V, Saravanan N, Donald E Waagen, Eiben AE. Springer; 1998:449 461 .

Gehlhaar DK, Verkhivker G, Rejto PA, Fogel DB, Fogel LJ, Freer ST: Docking conformationally flexible small molecules into a protein binding site through evolutionary programming. In Proceedings of the Fourth International Conference on Evolutionary Programming: 1-3 March 1995; San Diego Edited by: John R McDonnell, Robert G Reynolds, David B Fogel. MIT Press; 1995:615-627.

Gopalakrishna G, Ithman MH, Lauriello J. Update on New and Emerging Treatments for Schizophrenia. Psychiatric Clinics of North America. 2016; 30; 39(2):217-38.

Khare CP. Indian medicinal plants: an illustrated dictionary. Springer Science and Business Media; 2008; 22: 421.

Kim S, Thiessen PA, Bolton EE, Chen J, Fu G, Gindulyte A, Han L, He J, He S, Shoemaker BA, Wang J, Yu B, Zhang J, Bryant SH. PubChem Substance and Compound databases. Nucleic Acids Res. 2016; 44(D1):D1202-13. 
Laruelle M. Schizophrenia: from dopaminergic to glutamatergic interventions. Current opinion in pharmacology. 2014; 28; 14:97-102.

Lingjaerde O, Ahlfors UG, Bech P, Dencker SJ, Elgen K. The UKU side effect rating scale: A new comprehensive rating scale for psychotropic drugs and a cross-sectional study of side effects in neuroleptic-treated patients. Acta Psychiatrica Scandinavica. 1987; 76(s334):1-00.

Linstrom PJ and Mallard WG, Eds., NIST Chemistry WebBook, NIST Standard Reference Database Number 69, National Institute of Standards and Technology, Gaithersburg MD, 20899, http://webbook.nist.gov, (retrieved October 28, 2016).

Mailman RB, Murthy V. Third generation antipsychotic drugs: partial agonism or receptor functional selectivity? Curr Pharm Des. 2010;16(5): 488-501.

Maramai S, Gemma S, Brogi S, Campiani G, Butini S, Stark H, Brindisi M. Dopamine D3 receptor antagonists as potential therapeutics for the treatment of neurological diseases. Frontiers in Neuroscience. $2016 ; 10$.

Meltzer HY. Update on typical and atypical antipsychotic drugs. Annual review of medicine. 2013; 64:393-406.

Micheli F, Heidbreder C. Dopamine D3 receptor antagonists: a patent review (2007-2012). Expert opinion on therapeutic patents. 2013; 23(3):363-81.

Muralidharan P, Srikanth J. Anti epileptic activity of Morinda citrifolia linn fruit extract. Journal of Chemistry. 2010;7(2):612-6.

Owens DC. A guide to the extrapyramidal side-effects of antipsychotic drugs. Cambridge University Press; 2014 Apr 10.

Pandy V, Narasingam M, Mohamed Z. Antipsychotic-like activity of Noni (Morinda citrifolia Linn.) in mice. BMC complementary and alternative medicine. 2012;12(1):1.

PDB ID: 3PBL. Chien EY, Liu W, Zhao Q, Katritch V, Han GW, Hanson MA, Shi L, Newman AH, Javitch JA, Cherezov V, Stevens RC. Structure of the human dopamine D3 receptor in complex with a D2/D3 selective antagonist. Science. 2010; 330(6007):1091-5.
PDB ID: 5AER. Pandalaneni S, Karuppiah V, Saleem M, Haynes LP, Burgoyne RD, Mayans O, Derrick JP, Lian LY. Neuronal Calcium Sensor-1 Binds the D2 Dopamine Receptor and G-proteincoupled Receptor Kinase 1 (GRK1) Peptides Using Different Modes of Interactions. Journal of Biological Chemistry. 2015; 290(30):18744-56.

Roberts RJ, Findlay LJ, El-Mallakh PL, El-Mallakh RS. Update on schizophrenia and bipolar disorder: focus on cariprazine. Neuropsychiatric Disease and Treatment. 2016;12:1837.

Sánchez JP, Ellenbroek BA. Preclinical Effects of Antipsychotic Drugs. 2016; 1-16.

Shen WW. A history of antipsychotic drug development. Comprehensive psychiatry. 1999 Dec 31; 40(6):407-14.

Srikanth J, Muralidharan P. Antiulcer activity of Morinda citrifolia Linn fruit extract. Journal of Scientific Research. 2009; 1(2):34552 .

Stradford D, Vickar G, Berger C, Cass H. Complementary and Alternative Medicine Treatments in Psychiatry. 2012: 17.

Thomsen R, Christensen MH: MolDock: A new technique for high-accuracy docking. J Med Chem 2006, 49:3315-3321.

Wishart DS, Knox C, Guo AC, Shrivastava S, Hassanali M, Stothard P, Chang Z, Woolsey J. DrugBank: a comprehensive resource for in silico drug discovery and exploration. Nucleic Acids Res. 2006 Jan 1;34 (Database issue):D668-72.

Yang JM, Chen CC: GEMDOCK: A generic evolutionary method for molecular docking. Proteins 2004, 55:288-304.

\section{How to cite this article:}

Jeyabalan S, Subramanian K, Cheekala UMR, Krishnan C. GC-MS analysis and in-silico antipsychotic activity of Morinda citrifolia (Indian Noni). J App Pharm Sci, 2017; 7 (04): 089-095. 